Т.В. Чабан, Б.М. Пясецький

\title{
ІСТОРИЧНІ ВІХИ БОРОТЬБИ З ІНФЕКЦІЙНИМИ ХВОРОБАМИ НА ПІВДНІ УКРАЇНИ ТА ПЕРША КАФЕДРА ІНФЕКЦІЙНИХ ХВОРОБ
}

\author{
Одеський національний медичний університет
}

Описано історію становлення першої в Україні кафредри інфекційних хвороб в Одесі, а також заслуги видатних вітчизняних вчених, які стояли біля витоків чієї історичної події- М.Ф. Гамалії, Г.М. Мінха, О.О. Мочутковського, В.А. Хавкіна, Д.К. Заболотного, В.К. Стефранського. Стисло охарактеризовано постаті їх відомих послідовників - Л.К. Коровицького, Г.О. Гринберга, Р.П. Наумової, В.П. Ліпковського та ін.

Ключові слова: Україна, інфекційна лікарня, кафредра інфекційних хвороб, вчені.

Інфекційні хвороби відомі людству з давніх часів, описані великим Гіппократом і Авіценою. Старогрецький фрілософр-матеріаліст, лікар Демокрит висловив думку, що «хвороби викликаються крихітними організмами, що проникають в тіло людини і тварини і живляться його кров'ю». Проте це геніальне передбачення ще багато віків залишалося ніким не підтвердженим.

Інфектологія як наука почала зароджуватися внаслідок бурхливого розвитку бактеріології, обумовленого відкриттям збудників найнебезпечніших інфекційних Хвороб у XIX столітті. Тривалий час викладання курсу інфекційних хвороб проводилося на терапевтичних і педіатричних кафредрах, відомості про інфекційні хвороби були включені в курси загальної і спеціальної патології. В 1896 р. існувала лише одна кафредра інфекційних хвороб при Військово-медичній академії в Петербурзі. А 14 липня 1921 р. в Одеському медичному інституті була створена кафредра інфекційних хвороб, що стало підсумком діяльності декількох поколінь одеських лікарів і вчених, які створили умови і заклали фрундамент для будівництва школи інфекціоністів.

У XVIII столітті тільки на території півдня України було зареєстровано 15 епідемій чуми. Данило Самойлович (Сушковський) брав участь в ліквідації дев'яти 3 них. Більше 20 років воював він 3 грізною хворобою, розтинав загиблих від чуми, інспектував госпіталі, керував портовими карантинами, виїжджав у ті поселення, де виникали спалахи чуми. Вперше в Україні він зробив детальний опис клінічної картини чуми, вивчив умови її поширення і патологічну анатомію, написав відому роботу «Опис чуми, яка була в Херсоні в 1784 році».

В 1803 р. він зробив першу спробу інокуляції проти чуми, використовуючи для цього вміст дозрілого бубону хворого чумою. Таким чином він намагався знайти спосіб щеплення ослабленого заразного початку.

Багаторічні дослідження Д. Самойловича узагальнені в його фрундаментальній праці «Краткое описание микроскопических исследований о существе яда язвенного» (1792-1794). Міжнародним визнанням заслуг Д. Самойловича у боротьбі з чумою було обрання його почесним членом 12 зарубіжних академій.

У XIX столітті м. Одеса стає найбільшим економічним і культурним центром на півдні країни. Одеський порт по товарообігу поступається тільки Санкт-Петербургу. Розвивається промисловість, швидко росте населення міста. Особливість географічного положення міста як великого морського порту, відкритого для міжнародних відносин, обумовлює необхідність організації і проведення постійних карантинних і санітарно-протиепідемічних заходів. I не випадково однією з перших медичних установ в Одесі був морський карантин, створений в рік заснування міста.

Більше 200 років тому Одеса перенесла наймасштабнішу у своїй історії епідемію чуми. На той час населення міста складало 25 тисяч. 3 них загинуло більше 2600. Усього чума відвідувала Одесу вісім разів. Уперше хвороба потрапила в Південну Пальміру через три роки після її заснування з моряками барки «Святий Миколай», що прибула з Константинополя. Екіпаж, злякавшись тривалої ізоляції в портовому карантині, кинув судно і пішов на шлюпках у відкрите море. Міська влада прийняла рішення вивести барку на мілину і там спалити 3 усіма товарами і речами. Так було припинено можливу епідемію.

Достатньо відомий опис чуми 1837 р. в Одесі, зроблений видатним вченим Е.С. Андрієвським. Привертає увагу ретельність розслідування ходу епідемії. Як пише 
Е.С. Андрієвський, усіх «сомнительных/подозрительных/ больных немедленно посещали врачи, которые давали заключение, при получении которого к больному направлялся чиновник для исследования источника заразы и открытия путей дальнейшего ее распространения».

Результати обстеження були узагальнені Е.С. Андрієвським і представлені ним рисунком, що показує у вигляді «родословного дерева ход и распространение заразы, постигшей Одессу в 1837 году». В 1901-1902 рр. виникла типова портова епідемія чуми в Одесі, коли спостерігалася значна епізоотія серед щурів. Але масових захворювань серед людей не було. Д.К. Заболотний відмітив, що «...почти все случаи были бубонные, и притом бубоны паховые, что указывает на заражения через кожу ног». При появі перших випадків захворювань у місті були вжиті екстрені заходи. Хворих поміщали в ізольоване відділення міської лікарні. Люди, які контактували з хворими, витримувалися впродовж 6-10 днів у будинках обсервацій. Речі хворих і їх будинки ретельно дезінфікувалися. Під керівництвом М.Ф. Гамалеї спеціальними загонами була проведена величезна дератизаційна робота.

М.Ф. Гамалія починав лікарську діяльність у клініці нервових хвороб, де проявив себе як талановитий лікар, глибоко і серйозно осмислюючи проблеми пацієнтів. Але продовжити зайняття невропатологією М.Ф. Гамалії не вдалося - життя розпорядилося інакше. В 1885 р. Л. Пастером було зроблено успішне щеплення проти сказу, i товариство лікарів, за рекомендацією І.І. Мечникова, відряджає молодого лікаря до Парижу для ознайомлення $з$ методом приготування вакцини.

Л. Пастер високо оцінив здібності цього лікаря, про що і повідомив у листі в Одесу, даючи згоду на відкриття прищепної станції.

Так, завдяки двом талановитим ученим, Л. Пастеру і його послідовнику М.Ф. Гамалії, 11 червня 1886 р. в Одесі відкрилася перша в Росії і друга у світі станція для щеплень проти сказу. Незабаром, завдяки працям І.І. Мечникова і М.Ф. Гамалії, ця лабораторія здобула світову популярність. Сюди приїжджали з Петербурга, Сибіру, з Кавказу, навіть з Туреччини й Австрії. Лікарі 3 різних губерній відвідували станцію, де навчалися досвіду роботи. В результаті всюди стали виникати антирабічні станції, на їх базі - бактеріологічні лабораторії, а потім й інститути з вивчення інфекційних хвороб і розробки методів боротьби з ними.

М.Ф. Гамалія зібрав величезний практичний матеріал, що дозволив йому удосконалити вакцини і описати не відому раніше паралітичну форму сказу. Не випадково, коли в Європі раз за разом стали виникати збої в застосуванні пастерівських вакцин, Л. Пастер звернувся саме до нього з проханням захистити його метод від провалу. I М.Ф. Гамалія, піддавши глибокому аналізу невдалі спроби вакцинації у Франції і в Англії, знайшов причини неефективності вакцин і зміг аргументовано довести комісії неспроможність звинувачень на адресу Л. Пастера.

Але лише чумою і сказом коло інтересів М.Ф. Гамалії не обмежувалося. Він встановив водний шлях зараження холерою і вказав спосіб оберігання населення через впорядкування водопостачання. Микола Федорович відкрив у птахів вібріон, схожий, як він довів надалі, 3 холерним, і назвав його вібріоном І.І. Мечникова. Накопичений досвід боротьби з холерою послужив темою докторської дисертації «Этиология холеры с точки зрения экспериментальной патологии». М.Ф. Гамалія першим запропонував використати для захисту від холери вбиті холерні бацили. Їх нешкідливість він випробував спочатку на собі, а потім на своїй дружині.

Будучи приват-доцентом Новоросійського університету, він з 1904 по 1909 рр. читав лекції «Про основи загальної бактеріології» і курс «Загальної патології», вів заняття з діагностики інфекційних захворювань у людей і тварин. Займався питаннями боротьби з віспою і тифрами, наполягав на загальному і обов'язковому віспощепленні. Керував Центральним інститутом бактеріології і епідеміології (інститут ім. М.Ф. Гамалії).

31872 р. в Одеській міській лікарні працював прозектором Георгій Миколайович Мінх. В 1874 р. у досвіді самозараження кров'ю хворого на поворотний тиор він довів заразливість її. Встановив, що дві форми сибірської виразки - кишкова і легенева - мають єдине походження. Автор класичних робіт про проказу, яку досліджував, беручи участь у спеціальних експедиціях в Херсонську і Таврійську губернії, в Туркестан (18801885), а також в Єгипет і Палестину (1890). Відстоював точку зору про заразність цієї хвороби, протиставляючи ії поширеній тоді концепції про спадковість прокази. У вітчизняній літературі $€$ повідомлення про те, що Г.М. Мінх ще в 1892 р. встановив фракт можливості перенесення висипного тифу одежною вошею. В 1928 р. фрранцузький бактеріолог Шарль Николь за те ж саме відкриття отримав Нобелівську премію по фрізіології і медицині. На 10 років раніше Р. Коха виявив нитки і спори палички сибірської виразки і описав їх як «світлозаломлювальні точки». Був першим вітчизняним патологоанатомом, який вивчав морфологію крові.

У нашій лікарні працював і О.О. Мочутковський, який вивчав заразність трьох тифрів - поворотного, висипного і черевного. Вивчення здійснювалося на людях - передусім на самому собі, близьких співробітниках, які погодилися на такі дослідження, і одночасно на тваринах - мавпах, кролях, собаках і кішках. О.О. Мочутковський повторив вже відомий досвід Г.М. Мінха самозараження, зробивши 6 спроб, вивчав питання патогенезу і епідемі- 
ології. О.О. Мочутковський вивчав заразність не лише крові, але й молока, поту, слини, сечі, фекалій. Спостереження і досліди О.О. Мочутковського, проведені ще на зорі розвитку науки про висипний тифр, стали основою сучасного вчення про патогенез і епідеміологію цієї інфекції. Він був організатором і редактором (1892-1896) «Южнорусской медицинской газеты» в Одесі.

Володимир Аронович Хавкін - улюблений учень I.І. Мечникова - відомий створенням холерної вакцини, яку випробував на собі. В 1896 р. у Бомбеї, під час спалаху чуми, організував протичумну лабораторію і створив першу в історії людства античумну вакцину.

Д.К. Заболотний займався також вивченням епідеміології холери. У роботах по холері він обґрунтував епідеміологічне значення холерного вібріононосійства і дав оцінку його окремих видів у здорових людей, показав (разом із І.Г. Савченком) есрективність пероральної імунізації і вакцинації проти холери, створивши, таким чином, основи цілісного вчення про епідеміологію холери.

Д.К. Заболотний в 1920-1923 рр. був ректором Одеської медичної академії (незабаром реорганізованої в Одеський медичний інститут), де створив першу в Росії кафредру епідеміології (1920). В 1928 р. переїхав у Київ у зв'язку з обранням президентом АН УРСР.

Д.К. Заболотний опублікував понад 200 наукових робіт, присвячених, головним чином, етіології, патогенезу, епідеміології і профрілактиці холери і чуми. Він брав участь у ліквідації епідемій холери (1894, 1909, 1910 , 1918) і чуми в Росії, очолював ряд експедицій по вивченню чуми в Індії, Месопотамії, на Аравійському півострові, в Монголії, Маньчжурії, Китаї (1897, 1898, 19101911), Ірані (1899), Шотландії (1900) та ін. Узагальнивши матеріали, зібрані під час цих експедицій, Д.К. Заболотний уперше (1899) висунув гіпотезу про те, що дикі гризуни (ховрахи і тарбагани) є хранителями збудника чуми в природі і джерелом зараження людини.

Творцем і першим завідувачем кафедри інфекційних хвороб, її беззмінним керівником до 1949 р. був видатний вітчизняний вчений і клініцист В'ячеслав Карлович Стефранський. Нам вдалося відшукати цінні оригінальні документи - тодішні диплом і лікарську присягу В.К. Стефранського (фрото 1). В Одеській міській лікарні В'ячеслав Карлович працював з 1893 р., відразу після закінчення медичного фракультету в університеті св. Володимира у м. Києві. Спочатку в терапевтичному, потім - в заразному відділенні, яке очолив у 1908 р. 31897 р. В.К. Стефанський працює також на бактеріологічній станції. Тут почалася його наукова діяльність, у 1906 р. на медичному фракультеті Новоросійського університету захистив докторську дисертацію «Кислотоупорные бактерии. Заболевание кожи и лимфатических желез у крыс, сходное с проказой», в якій дав точний і вичерпний опис як макроскопічної, так й етіологічної картини лепри щурів, відкрив збудника цієї хвороби - Mycobacterium leprae murium.

На медичному фракультеті Новоросійського університету В.К. Стефранський першим увів приват-доцентський курс заразних хвороб, а також вів курс бактеріології і інфекційних хвороб на Вищих жіночих медичних курсах в м. Одесі.

Вперше в Росії в 1910 р. в Одесі профресором В.К. Стефанським застосована сироватка для лікування бубонної форми чуми. Симптом Стефранського - драглисте тремтіння тканин, що викликається ударом перкусійного молоточка в місці набряку - спостерігається при шкірній фрормі сибірки.

В'ячеслав Карлович Стефранський є автором першого вітчизняного підручника з інфекційних хвороб, що витримав два видання. Перу В.К. Стефранського належать більше 70 наукових робіт, у тому числі 4 монографрії, присвячені клініці і лікуванню туберкульозу, скарлатини, дисртерії, кашлюку, кору, дизентерії, амебіазу, холери, чуми, поворотного і висипного тифрів, малярії, сапа, грипу («іспанка»), менінгококової інфекції тощо, запобіганню ускладнень при антирабічних щепленнях, профрілактиці анафрілактичного шоку. За 56 років діяльності в галузі медицини і охорони здоров'я В'ячеслав Карлович створив свою школу лікарів-інорекціоністів, ученихмедиків і викладачів медичних навчальних закладів.

На кафредрі працювали: Лациник Є.В., Куперман О.Б., Стесранська А.В., Баумштейн І.А., Черьомушкіна Л.І., Недоступ Ф.І., одним з перших клінічних ординаторів був військовий лікар Полянський М.С.

В 1949 р. завідувачем кафедри інфекційних хвороб Одеського медичного інституту був обраний д. мед. н., професор, засл. діяч науки і техніки УРСР Леонід Костянтинович Коровицький. Професор Л.К. Коровицький - видатний вчений, блискучий лектор, мав величезний авторитет і повагу у науковому світі країни. Він вимагав від своїх учнів не лише знань з інфрекційних хвороб, але й паразитології, внутрішніх хвороб. Під його керівництвом на кафедрі інорекційних хвороб працювали: д. мед. н. Гринберг Г.О., професор Наумова Р.П., професор Ліпковський В.П., професор Михайлова А.М., профресор Дорошенко К.Г., Проскуров В.О., Годлевський В.В., Михайлевська Л.А., Богданюк Л.С., Борисова Г.О. та ін. У період широкого поширення малярії в південних регіонах України за ініціативою Л.К. Коровицького створювалися протималярійні станції, було почато систематичне навчання медичного і допоміжного персоналу навичкам виявлення і лікування хворих з малярією. Результатом цієї роботи стало «Практическое пособие по малярии» (Л.К. Коровицький і співавт.). Ця монографрія витримала 5 видань. 


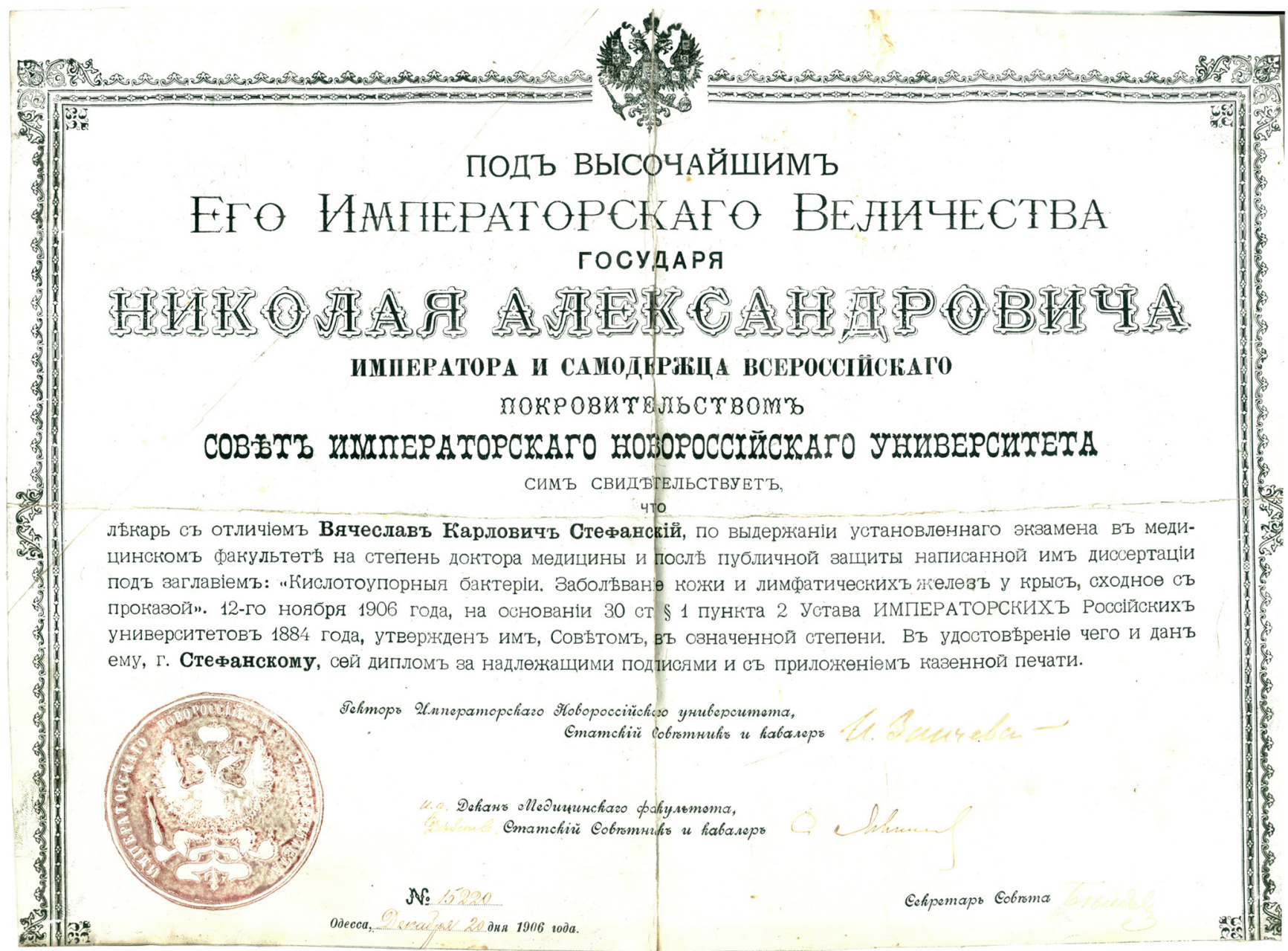

Фото 1. Диплом і лікарська присяга В.К. Стесранського. 


\section{ОГЛЯДИ ТА ЛЕКЦІї}

У цей період співробітники кафедри також брали активну участь у ліквідації спалаху поліомієліту. Одне з відділень інфекційної лікарні було відведено для госпіталізації хворих із поліомієлітом, воно було оснащене унікальною апаратурою для реабілітації тих, хто перенесли поліомієліт.

Л.К. Коровицький одним з перших в Україні почав вивчати поширення токсоплазмозу. Він створив консультативно-методичний кабінет при міській інфекційній лікарні, де проводилося масове обстеження осіб, у яких був запідозрений токсоплазмоз, а також усіх вагітних жінок. Створений ним центр з токсоплазмозу працює й сьогодні. Була видана монограсрія «Токсоплазмоз».

Упродовж багатьох років колектив кафедри працював над вивченням клініки, розробляв методи діагностики і лікування бруцельозу. Результати наукових досягнень висвітлені в монограсрії «Бруцельоз».

Наукову школу проф. Л.К. Коровицького за роки його роботи пройшли сотні лікарів-інфрекціоністів. Тоді в Україні були досить поширені такі хвороби, як черевний тифр, висипний тиф, поворотний тиф, малярія, дифтерія. Співробітники кафредри брали активну участь у ліквідації цих хвороб. Результатам багаторічних досліджень клініки, терапії сироваткової хвороби присвячені дисертація і монографії Ф.К. Іванова.

В 1968 р. кафедру інсрекційних хвороб очолив просресор В.П. Ліпковський, який до цього керував такою ж кафедрою в Чернівецькому медичному інституті. В.П. Ліпковський приділяв велику увагу поліпшенню матеріальної бази кафедри для навчального процесу і наукової роботи. Основними напрямами науково-дослідної роботи касредри за керівництва В.П. Ліпковського було вивчення патогенезу і патогенетичної терапії інфекційних хвороб. У 1970 р. в Одесі вибухнув спалах холери. Співробітники кафедри разом з лікарями інфекційної лікарні цілодобово надавали невідкладну допомогу хворим. Саме в період цього спалаху для лікування хворих співробітниками кафредри були впроваджені сучасні методи терапії, що дозволило значно понизити летальність.

Досвід, набутий під час спалаху холери, дозволив викладачам кафедри брати участь в організації протиепідемічних і лікувальних заходів при всіх спалахах холери на півдні України (Одеська, Миколаївська, Херсонська області, АР Крим).

Профресор В.П. Ліпковський і профресор Р.П. Наумова підготували підручник «Практичні заняття з інфеекційних хвороб», який витримав 2 видання. В.П. Ліпковський - співавтор підручника з тропічних хвороб, автор понад 100 наукових робіт, у тому числі монографрій. В.П. Ліпковський підготував 15 кандидатів і 1 доктора медичних наук.
У 1990 р. завідувачем кафедри інсрекційних хвороб був обраний д. мед. Н., профеесор Є.В. Нікітін. Під його керівництвом співробітники кафедри вивчали питання патогенезу і патогенетичного лікування інфекційних хвороб i, зокрема, механізму цитолізу гепатоцитів у хворих на вірусні гепатити, розробляли нові методи патогенетичного і етіотропного лікування вірусних гепатитів. Засл. діяч науки і техніки України, лауреат Державної премії України, професор Є.В. Нікітін - автор понад 150 наукових робіт, авторських свідоцтв і патентів на винаходи, співавтор монографії «Медицина катастроср» і підручника «Організація медичної служби на кораблях і частинах ВМФ України», за редакцією Є.В. Нiкітіна видано курс лекцій «Інфрекційні хвороби». Розроблена ним теорія механізму цитолізу гепатоцитів при вірусних гепатитах широко визнається в нашій країні і за кордоном. Під керівництвом $Є$.В. Нікітина виконано 9 кандидатських і 1 докторська дисертація. Профресор $€$.В. Нікітін і сьогодні продовжує працювати на кафедрі.

Восени 1990 р. в Татарбунарському районі Одеської області були зареєстровані випадки туляремії. Колектив кафедри надавав консультативно-лікувальну допомогу хворим.

У 1992 р. в Одесі діагностовано перші випадки дифтерії. Складність клінічної діагностики була обумовлена тривалим періодом відсутності таких хворих в Україні. Завдяки спільній роботі співробітників кафедри і лікарів практичної охорони здоров'я і цей спалах був ліквідований.

Д. мед. н., профресор К.Л. Сервецький очолював кафедру інфееційних хвороб з 2002 по 2015 рр. Костянтин Леонідович пройшов славний трудовий шлях, почавши його лікарем, завідувачем відділення, потім головним лікарем, з 1987 по 1994 рр. очолював управління охорони здоров'я Одеської обласної держадміністрації, працював асистентом, доцентом кафедри інсрекційних хвороб Одеського національного медичного університету. Будучи вихованцем наукової школи професора Л.К. Коровицького, К.Л. Сервецький створив одну із серйозних шкіл інсрекціоністів в Україні. Він прагнув збагатити медицину новими підходами, концепціями, поглядами.

За нетривалий час під його керівництвом захищено 2 докторські і 9 кандидатських дисертацій. Основний напрям наукової діяльності: патогенез, клінічні особливості, методи лікування вірусних хвороб. 3 різних розділів сучасної медицини профессором К.Л. Сервецьким опубліковано більше 150 наукових робіт, він $є$ автором 17 винаходів, співавтором підручників, наукових посібників і монографрій з питань інфектології.

У 2005 р. Наказом Президента України йому присвоєно звання заслуженого лікаря України. Костянтин 
Леонідович був також першим директором Університетської клініки № 1 Одеського національного медичного університету, де об'єднав висококваліфікованих фрахівців різних медичних спеціальностей. Це дозволило забезпечити високий рівень діагностики і лікування хворих, сучасну якісну підготовку лікарів.

Сьогодні кафедру очолює доктор медичних наук, профресор Тетяна Володимирівна Чабан - учениця і продовжувач справи професора Є.В. Нікітіна та профресора К.Л. Сервецького. Професор Т.В. Чабан - автор понад 180 наукових праць, співавтор монографій, підручників, навчальних посібників, патентів на винаходи, під її керівництвом захищені 3 кандидатські дисертації.

Науковим напрямом кафедри й нині залишається розкриття патогенезу та удосконалення терапії вірусних інсекцій, у т.ч. хронічних вірусних гепатитів, використання препаратів з противірусним і антиоксидантним механізмом дії. Сьогодні на кафедрі працюють 2 професори, 9 доцентів, 4 кандидати мед. наук і 6 асистентів. На кафедрі виконуються 2 докторські і 2 кандидатські дисертації.

У жовтні 2015 р. відкрито другу базу кафредри - це клініка іноекційних захворювань Військово-медичного клінічного центру Південного регіону.

На кафедрі проходять навчання студенти V i VI курсів медичного і міжнародного фракультетів (у т. ч., проводиться викладання англійською мовою) і IV курсу стоматологічного факультету. Також на кафедрі інфекційних хвороб проходять навчання інтерни-інфекціоністи та інтерни суміжних кафедр.

32012 р. розпочато підготовку лікарів-курсантів: передатестаційні цикли, стажування, цикли тематично- го удосконалення - «Найважливіші гельмінтози і паразитарні хвороби людини», «ВІЛ-інфекція/СНІД. Дотестове і післятестове консультування на ВІЛ-інфекцію», «Вірусні гепатити», «Амбулаторно-поліклінічна допомога інфекційним хворим».

Співробітники кафредри, крім педагогічної, наукової та лікувальної роботи в інфекційній лікарні, надають кваліфіковану консультативну допомогу в лікувальних установах міста Одеси, Одеської області та інших областей Півдня України.

\section{HISTORICAL LANDMARKS OF INFECTIOUS DISEASES FIGHT AT SOUTH OF UKRAINE AND FIRST DEPARTMENT OF INFECTIOUS DISEASES}

T.V. Chaban, B.M. Piasetsky

Odesa National Medical University

SUMMARY. The history of the first Ukrainian Department of Infectious Diseases formation was describe. It was found in Odesa and achievements of the famous scientist who stood at the origins of this historic event by M.F. Hamaleya, H.M. Minkh, O.O. Mochutkovsky, V.A. Khavkin, D.K. Zabolotny, V.K. Stefansky. Briefly described figures of famous followers - L.K. Korovytsky, H.A. Hreenberh, R.P. Naumov, V.P. Lipkovsky and others.

Key words: Ukraine, Infectious Diseases Hospital, Department of Infectious Diseases, scientists.

Отримано 4.08.2016 p. 